\title{
Chemistry in India.
}

$D^{\mathrm{R}}$ R. M. O. FORSTER, in his address to the twelfth Indian Science Congress, has preached a sermon which is not likely to be forgotten by those who were privileged to hear it or by those who have had an opportunity of reading it. Phrased in the happy manner which came to many as a revelation on the occasion of his address to Section B of the British Association at Edinburgh, it deals with numerous fundamental and intimate questions which are exercising the minds of many thoughtful men and women at the present time. Probably no one can do this kind of thing quite so well as Dr. Forster, for he enhances his constitutional optimism by a flow of language which overwhelms the pessimist and carries the reader from the start to the finish along a smooth stream of pleasing rhetoric, past a countryside replete with all that is beautiful and satisfying, only dallying here and there to point out to the traveller some piece of Nature's handiwork more entrancing than the rest, or pausing to express a feeling of admiration for the manner in which scientific man has acquitted himself. It is only afterwards that the reader, whose mind, after his journey, will be in a pleasant condition of altruistic confusion, will wonder what it is all about. If he is an incorrigible pessimist, and wishes to retain his sanity, he will be well advised to let the first impression stand and not to examine more closely into the nature of the raw material from which Dr. Forster has woven his fascinating fabric. If, like most of us, he is a man of the world without any unhealthy bias towards extreme optimism or extreme pessimism, but, taking things much as he finds them, bestows neither premature praise nor expresses hasty condemnation, he will find much with which he can agree and a great deal to inspire thought and contemplation.

To Dr. Forster's audience the address should be of inestimable value, for India needs scientific stimulation and inspiration far more than any other country of her importance in the world. Her immense natural resources and the mental calibre of her races ought to ensure her a foremost place, both scientifically and commercially, among the nations; yet she remains chained and fettered, and probably only one in a million of her inhabitants will be in a position to take to heart the message Dr. Forster sends them. Nevertheless, conditions are changing for the better, and the past twenty years have marked a notable advance in the scientific status of the Indian Empire.

The far-sighted vision of an exceptional man led to the founding of the Indian Institute of Science at Bangalore, but it was not until eleven years after the inception of the scheme that all difficulties were removed and the vesting order was signed. Meanwhile, the first director, Dr. M. W. Travers, had been appointed and had drawn up the necessary plans for the organisation and equipment of the new Institute. It is undoubtedly due to the devotion and, indeed, self-sacrifice of Dr. Travers that the scheme assumed definite shape, and that the buildings and laboratories were ready to receive the first students in July I9I I. Slight changes in the original organisation were afterwards made, and at the present time there are three chief departments, namely, those of electrical technology, general and organic chemistry, and biochemistry; there is, moreover, a large central building in which the offices and library are housed, the excellence of the latter being due to the organising ability of Mr. C. F. H. Tacchella. After the retirement of Dr. Travers in I9I4, the post of director was held by Sir Alfred Bourne until I9I9 when, after Dr. Alfred Hay had acted as officiating director for two years, the present holder of the office, Dr. M. O. Forster, was appointed.

It was probably inevitable that, during its earlier years, the Institute should have devoted itself to many ad hoc problems arising out of the then existing conditions of Indian manufactures. The intention of the founder had been to establish a post-graduate university institution having for its particular object the promotion of advanced study and original research, with special regard to the educational and economic interests of India, but, at that time, advanced education in India was not in a condition to supply a sufficient number of properly trained postgraduate students, and, in those early days, it must have been exceedingly difficult to find the right men to carry out the fundamental research upon which to base the many important industries of the country. Still, in the efficient hands of Dr. Sudborough, Dr. Fowler, Dr. Watson, and Dr. Hay, much was done, and the early record of the Institute bears witness to the fact that, despite the obvious difficulties, the research work accomplished supplied material for the improvement of many industries which had hitherto been built on the rule-of-thumb and traditional methods so characteristic of Indian manufacturing procedure as a whole.

The appendix to the fifteenth annual report of the Council of the Institute, dated I924, is now to hand, and it is evident, from the comprehensive list of investigations which the report shows are being carried out by the three departments already mentioned, that important research work of a fundamental character is being pursued. The lists are indeed pleasing to read and will stimulate Indian graduates to enter the Institute in order to obtain that training in research methods which not only broadens the outlook, but, without which, it is useless for any chemist to hope to achieve real success in industrial work. For knowledge derived from lectures and books cannot supply the vision, the independence of thought, and the honesty of purpose which are essential to the development of the scientific soul, and Indians would do well to learn the lesson some of their confrères in the west find difficult to assimilate, which is embodied in the address given by Dr. Forster at Benares. JOCELYN THORPE.

\section{Local Natural History in Great Britain. ${ }^{1}$}

I OCAL scientific societies have their distinct and special place, with its incumbent responsibilities in the scientific life of the country, and it is well that this important fact should not be overlooked, par-

1 The North Staffordshire Field Club: Transactions and Annual Report, 1 The North Staffordshire Field Club: Transactions and Annual Report,
I923-24.
The South-Eastern Naturalist, being the Proceedings and Transactions of The South-Eastern Naturalist, being the Proceedings

The Liverpool Geological Society: Proceedings, vol. I4. Part I., session the sixty-fifth, $1923-24$. ticularly by the societies themselves. These, it is to be feared, do not always appreciate their obligations to organise and carry through schemes of scientific work which obviously come within their province. Intensive investigations, both systematic and ecological, of the fauna and flora of the country are problems pre-eminently suited to the activities of local societies. In fact, it will be only by the active co-operation and organisation of such societies that 